\title{
A diabeteses láb ischaemiás eredete. Epidemiológia, a diagnózis nehézségei, prevenciós és revascularisatiós lehetőségek
}

\author{
Kolossváry Endre dr. ${ }^{1}$ - Bánsághi Zoltán dr. $^{3}$ - Szabó Gábor Viktor dr. ${ }^{4}$ \\ Járai Zoltán dr. ${ }^{2}$ - Farkas Katalin dr. ${ }^{1}$
}

Szent Imre Egyetemi Oktatókórház, ${ }^{1}$ Angiológia, ${ }^{2}$ Kardiológia, Budapest

Semmelweis Egyetem, ${ }^{3}$ Általános Orvostudományi Kar, Radiológiai Klinika, ${ }^{4}$ Városmajori Szív- és Érgyógyászati Klinika, Érsebészeti Tanszék, Budapest

\begin{abstract}
A „diabeteses láb” mint multifaktoriális megbetegedés hátterében a neuropathia, infekció, csont- és lágyrész-eltérések mellett a legutóbbi évek epidemiológiai adatai alapján az alsó végtagi ischaemia szerepe egyre inkább hangsúlyossá válik. Cukorbetegségben az alsó végtagi ütőérszúkület rendkívüli mértékben fokozza az alsó végtagi fekélyképződés, valamint a minor és major amputáció kockázatát. A diabetesre jellemző klinikai megjelenés miatt az alsó végtagi ütőérszúkület felismerésére a hagyományos diagnosztikus eljárások korlátozottan alkalmazhatók. A hatékony diagnosztika alapfeltétele olyan vascularis központok elérhetősége, amelyek a szakmai ismeretek és rendelkezésre álló diagnosztikus eszközök segítségével alkalmasak a cukorbetegcsoportban az érbetegség időben történő detektálására. Az ischaemiás kórokra visszavezethető diabeteses láb kezelése során a hatékony gyógyszeres kezelés mellett az érátjárhatóság helyreállításának kiemelt fontosságot tulajdonítanak. Az érsebészeti és intervenciós radiológiai beavatkozások sikeresen előzhetik meg a végtagvesztést. Népegészségügyi érdek, hogy kiemelt vascularis centrumok alakuljanak, ahol az angiológusok, érsebészek, intervenciós radiológusok csoportjai a társszakmákkal együttmúködve lehetnek képesek multidiszciplináris módon az érbetegségek magas szintű szakmai ellátására. Orv. Hetil., 2017, 158(6), 203211.
\end{abstract}

Kulcsszavak: diabeteses láb, perifériás érbetegség, alsó végtagi amputáció

\section{Ischemic origin of diabetic foot disease. Epidemiology, difficulties of diagnosis, options for prevention and revascularization}

"Diabetic foot" as definition covers a multifactorial clinical condition. According to the recent epidemiological data, the role of lower limb ischemia is getting more influential over other pathological causes, like neuropathy, infections and bone or soft tissue deformity. In diabetes, vascular disease leads to increased risk for leg ulcers and minor or major amputations. The traditional diagnostic tools for recognition of peripheral arterial disease have limited value because of diabetes specific clinical manifestations. Available vascular centers with special expertise and diagnostic tools are the prerequisite for efficient diagnosis supporting timely recognition of peripheral arterial disease. In course of treatment of diabetic foot with ischemic origin, beyond effective medical treatment revascularization (open vascular surgery or endovascular procedures) has paramount importance for prevention of limb loss. Vascular teams of vascular specialists, vascular surgeons and interventional radiologist in dedicated centers in multidisciplinary cooperation with other professions represent public health issue in effective prevention.

Keywords: diabetic foot, peripheral arterial disease, lower limb amputation

Kolossváry, E., Bánsághi, Z., Szabó, G. V., Járai, Z., Farkas, K. [Ischemic origin of diabetic foot disease. Epidemiology, difficulties of diagnosis, options for prevention and revascularization]. Orv. Hetil., 2017, 158(6), 203-211.

(Beérkezett: 2016. október 24.; elfogadva: 2016. december 6.) 


\section{Rövidítések}

DEB = (drug-eluting balloon) gyógyszerkibocsátó ballon; DES $=$ (drug-eluting stent) gyógyszerkibocsátó stent; DSA = digitális szubsztrakciós angiográfia; $\mathrm{rTPA}=$ rekombináns szöveti plazminogén aktivátor; TBI = öregujj/kar nyomásindex; $\mathrm{TcPO}_{2}=$ transcutan oxigén parciális nyomás

A diabeteses láb mint klinikai entitás hátterében összetett kórok valószínűsíthető. Kialakulásáért a diabeteses neuropathia mellett a végtagot ellátó nagyartériák keringésének károsodása, kisérkeringési zavar, csont- és ízületi eltérések, infekciók változó arányú jelenléte tehető felelőssé $[1,2]$. A potenciális kimenetel, az érintett betegek életminőségének jelentős romlása, a diabeteses lábfekély, valamint a végtag elvesztésének veszélye a kérdést mind szúken vett orvosszakmai, mind tágabban értelmezett társadalompolitikai szempontból kiemelt jelentőségưvé teszi [3].

Az egyes etiológiai tényezők külön témaként kezelése nem jelenti azt, hogy valamelyiknek fontosabb szerepe lenne a többivel szemben. Az elkülönítés egyetlen magyarázata, hogy az egyes etiológiai faktorok önmagukban is rendkívül összetett, a cukorbetegségre specifikus jelleget mutatnak. Ennek megfelelően külön tárgyalásuk a megértést segíti.

A továbbiakban ezen elv szerint a diabeteses láb ischaemiás eredetének epidemiológiai, diagnosztikai és terápiás sajátosságait elemezzük.

\section{A diabeteses láb ischaemiás eredetének epidemiológiai vonatkozásai}

A cukorbeteg populációban kimutatható obliteratív verőérszűkület gyakoriságát két tényező határozza meg. A vizsgált populáció klinikai jellemzői mellett (1-es típusú vagy 2 -es típusú cukorbetegség, tünetmentes vagy tünetes betegkör, alsó végtagi fekély hiánya vagy jelenléte, amputáción átesettek) a kimutatásra szolgáló eljárás (kérdőív, perifériás erek tapintása, boka/kar index, UH/ CT/MR/DSA képalkotás) szerepe is lényeges.

A cukorbetegség, mint az alsó végtagi veróérszúkület kockázata, a perifériás érbetegség teljes klinikai spektrumában kimutatható (tünetmentes állapot-kritikus végtagi ischaemia). A különböző epidemiológiai vizsgálatokban a diabetes az érszükület kockázatát jelentősen emelte

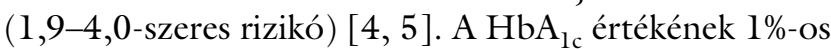
emelkedése az alsó végtagi verőérszúkuület kockázatát 28\%-kal emeli [6]. A két eltérés kapcsolatának erősségét fokozza az életkor előrehaladása, a cukorbetegség fennállásának ideje, a dohányzás, valamint a diabeteses neuropathia egyidejű fennállása. Az érszúkület súlyos formájában, a kritikus végtagi ischaemia megjelenésekor a cukorbetegséggel való kapcsolat még kifejezettebb. Több vizsgálat adatai szerint a kritikus végtagi ischaemiában szenvedő betegekben a diabetes-előfordulás 35$80 \%$ között van. Cukorbetegekben 10-20-szor gyakrab- ban fordul elö kritikus végtagi ischaemia, mint nem cukorbetegekben [7].

Azon túl, hogy a diabetes fokozza az alsó végtagi verőérszúkület kockázatát, az érszúkületben szenvedők állapotának klinikai kimenetele is rosszabb cukorbetegség fennállásakor.

Egy vizsgálat szerint érszúkületes betegek amputációs kockázatát a cukorbetegség ötszörösére emeli. Ugyanebben a populációban a cukorbetegek halálozásának kockázata háromszoros a nem cukorbetegekével összehasonlítva [8].

A cukorbetegséggel kapcsolatos alsó végtagi amputációkat 85\%-ban fekélyképződés előzi meg. A cukorbeteg populációban az alsó végtagi fekély élettartamra vonatkoztatott kockázatát 25\%-ra becsülik [1]. A fekély kialakulásának hátterét tekintve a korábbi, elsősorban a neuropathia szerepét hangsúlyozó állásponttól eltolódás figyelhető meg [9]. Az ischaemiás, neuroischaemiás mechanizmus szerepét egyre jelentősebbnek gondolják. Az EURODIALE vizsgálatot 10 európai ország 14 diabetesesláb-központjában végezték olyan cukorbetegek bevonásával, akiknek az alsó végtagján újonnan kialakult fekély keletkezett. A több mint 1200 bevont beteg prospektív vizsgálata során a boka/kar index meghatározásával átlagosan közel 50\%-ban (22-73\%) volt igazolható a perifériás érbetegség ténye [10]. Más vizsgálatok 10-60\% közöttinek találták az érszúkület gyakoriságát diabeteses alsó végtagi fekély fennállása esetén. A gyakori előfordulás mellett szembeötlő az adatok változékonysága, aminek hátterében az érszúküulet eltérő előfordulása, a fekélyek megjelenésének eltérő volta, valamint a változó betegbeutalási utak állhatnak [11]. A fenti, a diabeteses láb és perifériás érbetegséggel kapcsolatos adatok vélhetően alulbecsültek, mert cukorbetegség esetén a verőérszúkület anatómiai megjelenése, klinikai képe eltér, a diagnózis felállítása a nem cukorbetegekkel összehasonlítva nehézségekbe ütközhet.

A témakörben kevés magyarországi adattal rendelkezünk. A vélhetően perifériás érbetegséggel vagy cukorbetegséggel kapcsolatos alsó végtagi amputációkkal kapcsolatos adatok aggasztók. Az alsó végtagi major amputációk incidenciája 2004 és 2012 között lényegében nem változott. $\mathrm{Az}$ amputációk számaránya $\left(42 / 10^{5}\right)$ a nemzetközi közölt adatok átlagának több mint háromszorosa! A major amputációt elszenvedett betegek több mint 50\%-a cukorbeteg. Az amputáció kockázata az utóbbi betegkörben tizenötszörös a nem cukorbetegekkel való összehasonlításban. A comb magasságában végzett amputációk magas arányszáma (70\%), a primer, azaz olyan major amputációk arányszáma $(72 \%)$, amelyet egy éven belül nem előzött meg semmilyen revascularisatiós kísérlet, jelzik, hogy a kérdés égető [12]. Az alsó végtagi keringészavar felismerése és hatékony kezelése kiemelkedő fontosságú a diabeteses láb lehetséges szövődményeinek (fekély, amputáció) megelőzésében. 


\section{A perifériás érbetegség felismerésének sajátosságai cukorbetegségben}

Cukorbetegségben az alsó végtagi atherosclerosis patológiai megjelenésében különbözik a cukorbetegségben nem szenvedőkkel összehasonlítva. Jellemző az infrapoplitealis érrendszer fokozott érintettsége, a diffúz megjelenés, hosszabb szakaszokat érintő érelzáródás, az artériafal mediarétegének gyakori kalcifikációja, valamint a kollaterális keringés gyér volta. A nagyerek elváltozásaihoz gyakran társul a mikrocirkuláció funkcionális zavara. A bőr kapilláris rendszerében a vazoaktivitás csökkenése, az arteriovenosus söntök megnyílása csökkent perfúzióhoz vezet, ami tovább rontja a fekélygyógyulás esélyeit. A fenti, keringési rendszer szintjén észlelhetó eltérésekhez gyakran társul neuropathia, amely két eltérés együttese a keringési zavar klinikai felismerését jelentősen nehezíti [13].

Cukorbetegségben a perifériás érbetegség ugyan rontja a betegek alsó végtagi funkcionális kapacitását, azonban a típusos claudicatióval jellemezhető klinikai kép a betegek kisebb hányadában ismerhető csak fel [14].

A betegek sok esetben vagy nem jeleznek fájdalmat az egyidejűleg fennálló szenzoros neuropathia miatt, vagy a distalis megjelenés miatt nem a lábszárra, hanem a lábfejre lokalizálják fájdalmukat. A szöveti károsodás (fekély, gangraena) elsődlegesen a relatíve csökkent keringéssel bíró területeken jelentkezik (1. ábra). Kritikus végtagi ischaemia esetén is a végtag tapintásakor melegség érezhető a bőr-mikrokeringés szintjén megnyíló AV-söntök miatt [15].

A klinikai tünetek, a fizikális vizsgálat korlátai mellett, a perifériás érbetegség diagnózisának felállításakor hagyományosan javasolt Doppler- (boka/kar index) vizsgálatnak az értékelhetősége is csökkent a cukorbeteg populációban [16].

A boka/kar index meghatározásán alapuló diagnózis felállításakor a diabetes jelentősen növeli (4,3-szeres) az álnegatív eredmény kockázatát [17].

A hagyományos Doppler-vizsgálat alkalmazhatóságának korlátja cukorbetegségben több tényezőre vezethető vissza. Az elsősorban hosszú ideje fennálló diabetes esetén kialakuló, az artériák falának mediarétegére lokalizálódó kalcifikáció azt eredményezi, hogy a Doppler-mérés során a lábszárartériák nem komprimálhatók, így a boka magasságában a valódi nyomásnál magasabb értékeket mérünk. A jelenség különösen gyakori, amikor a cukorbetegséghez veseelégtelenség vagy neuropathia is társul [18]. A nem komprimálható ereknek köszönhetően a boka/kar index értéke emelkedett, ami részben értékelhetetlenné teszi a vizsgálatot $(\mathrm{BKI}>1,4)$ vagy elfedheti, maszkírozhatja az esetlegesen fennálló érszúkületet. Utóbbit támogatják azok a megfigyelések, amelyek szerint cukorbetegekben az egyébként normálisnak tekintett boka/kar index tartománya (BKI 0,9-1,4) esetén az elvégzett artériás color duplex vizsgálat $50 \%$ felett igazolta az érszúkület tényét [19]. Emelkedett boka/kar

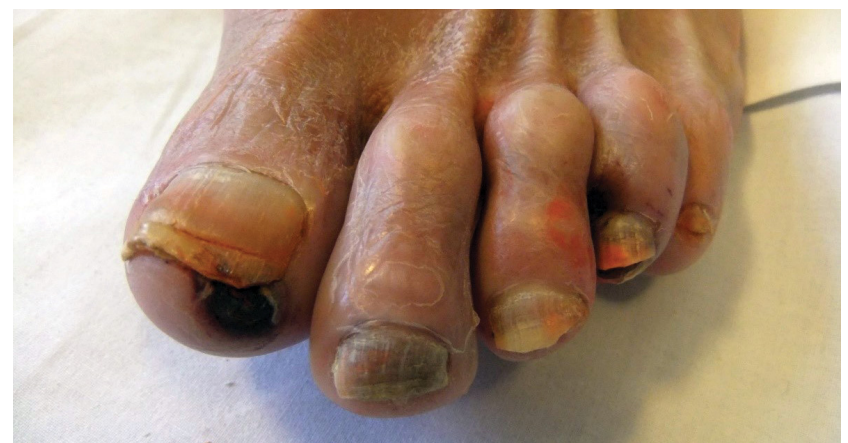

1. ábra

Ischaemiás eredetű diabeteses láb klinikai képe (Dr. Farkas Katalin anyagából)

index $(\mathrm{BKI}>1,4)$ esetén is nagy százalékban $(58 \%)$ volt igazolható hasonló módszerrel a perifériás érbetegség [20].

A nem komprimálható alsó végtagi artériák mellett további tényező, amely a hagyományos Doppler-vizsgálat alkalmazhatóságát korlátozza cukorbetegségben, az érszúkület diabetesre jellemző térd alatti lokalizációja. A tradicionális boka/kar index számítása során a magasabb bokanyomást (arteria dorsalis pedis vagy arteria tibialis posterior) vesszük alapul. Cukorbetegségben a lábszári artériák gyakori érintettsége esetén ez a módszer alulbecsülheti az érszúkület gyakoriságát [21].

Amennyiben a perifériás erek nem tapinthatók és az artériás Doppler-vizsgálat eredménye kétséges, alternatív diagnosztikus eljárások szükségesek, amelyek már elsősorban angiológiai központokban, illetve szakrendeléseken érhetők el.

A hagyományos boka/kar index meghatározása lehetséges alternatívája a folyamatos hullámú Doppler(CWD-) vizsgálat során nyert pulzushullám elemzése. $\mathrm{Az}$ egészséges keringésre jellemző artériás Dopplerspektrum a mérési ponttól proximálisan jelen lévő szignifikáns szűkület esetén megváltozik. A trifázisos hullámalak bifázisossá vagy monofázisossá válik, a hullámforma amplitúdója csökken, a görbe késő szakaszára jellemző reverz flow hullám komponense eltűnik [22] (2. ábra).

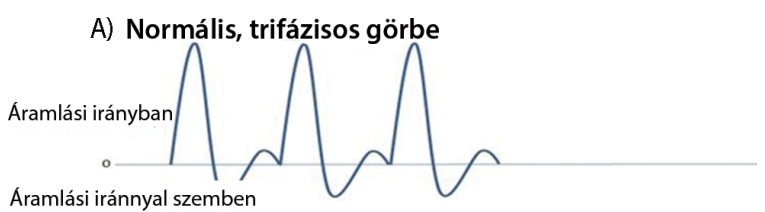

B) Szűkület utáni, bifázisos görbe

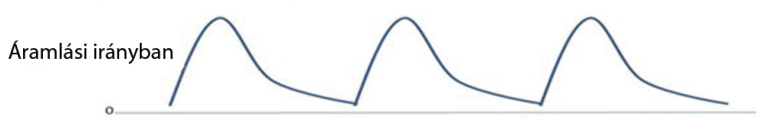

Áramlási iránnyal szemben

C) Elzáródás utáni, monofázisos görbe

Aramlási irányban

Aramlási iránnyal szemben

2. ábra Artériás Doppler-görbék típusai 


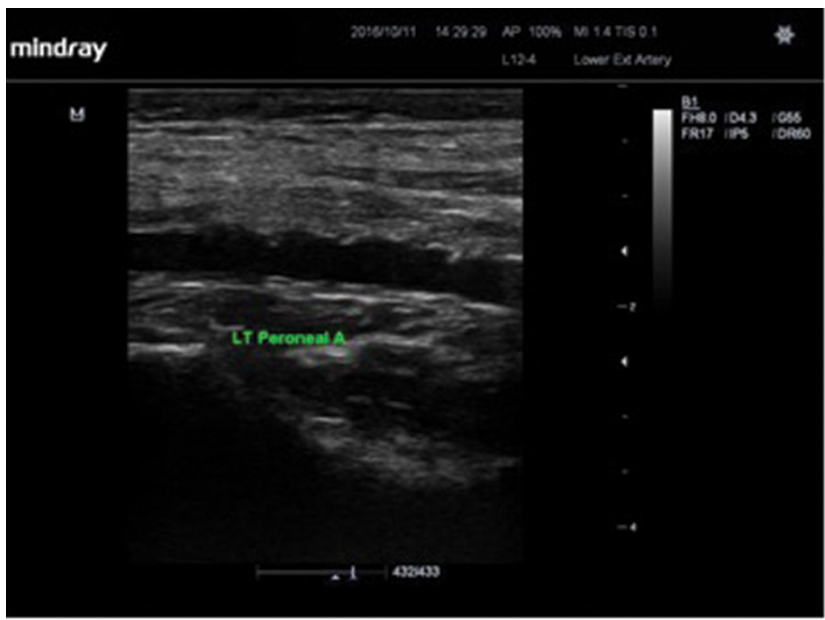

A) Arteria peronea falán diffúz meszesedés

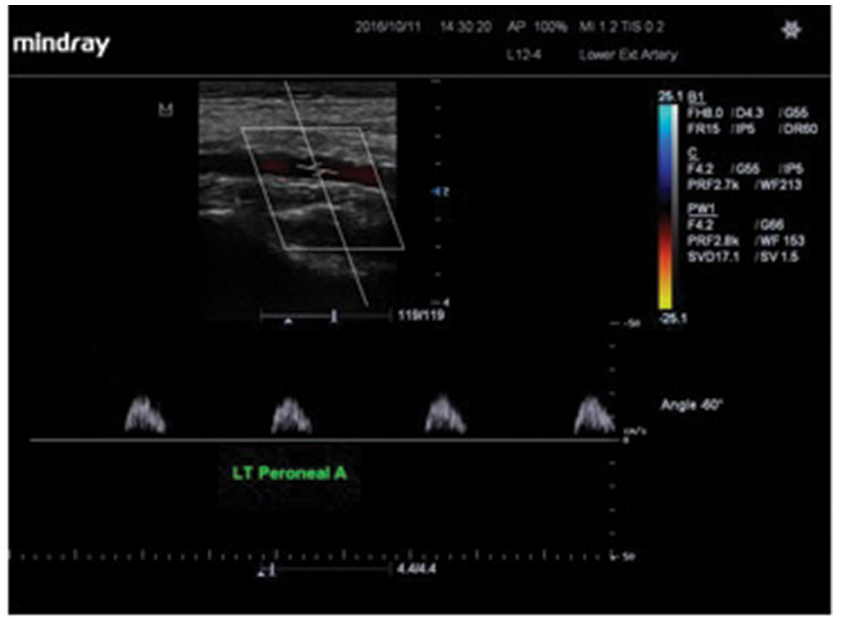

B) Arteria peronea bifázisos, deprimált keringés
A Doppler-hullám spektrumelemzése a perifériás érbetegség kimutatásának hatékony eszköze a cukorbeteg populációban [23].

A hullámgörbe elemzését nemcsak a folyamatos Doppler- (CWD-) eljárás, hanem a fotopletizmográfia, valamint az artériás color duplex vizsgálat is lehetővé teszi. Utóbbi esetében a hatékonyságot növeli, hogy az artériás áramlási spektrum detektálása mellett az ultrahangvizsgálattal megítélhető az érfal állapota, valamint kimutatható az alsó végtagi keringészavart okozó konkrét szúkület (3. ábra). A cukorbetegekre jellemző térd alatti lokalizáció, az esetleges kiterjedt kalcifikáció azonban az ultrahang-alkalmazás korlátját jelentheti [24].

A Doppler-eljáráson alapuló boka/kar index vizsgálatának további lehetséges alternatívája az öregujj artériás nyomásának meghatározása, valamint az ezt az értéket felhasználó öregujj/kar nyomásindex (TBI) számolása. Az eljárás előnye azon a megfigyelésen alapul, hogy a cukorbetegekre jellemző mediakalcifikáció a lábujjak artériáit ritkán érinti [25]. Ennek megfelelően, amennyiben rendelkezésre áll olyan nyomás mérését lehetővé tevő mandzsetta, ami az öregujjra illeszthető, valamint vagy fotopletizmográfiás, vagy lézeres Doppler-eljárással tudjuk detektálni az öregujj keringését, akkor a mediakalcifikáció hatását elkerülhetjük. Cukorbetegség esetén az öregujjban mért artériás nyomás abszolút értéke, valamint öregujj/kar nyomásindex meghatározása a perifériás érbetegség kimutatásának hatékony alternatív eszköze. A diagnosztikus TBI-határérték, ami alatt az érszúkület valószínűsíthető, a különböző tanulmányok eredménye alapján 0,6-0,7 között van [26].

A klinikai gyakorlatban, cukorbetegség esetén különösen, az alsó végtagi artériás perfúzió zavarának mérésére hatékony eszköz lehet a bőroxigenizáció vizsgálata. A transcutan oxigén parciális nyomásának vizsgálata $\left(\mathrm{TcPO}_{2}\right)$ elsősorban akkor javasolt, amikor diabeteses lábfekéllyel állunk szemben. Az elsődleges kérdés ilyen- kor, hogy hagyományos kezelés mellett a fekélygyógyulás várható-e, vagy az előrehaladott ischaemia miatt a revascularisatio az előfeltétele a fekély hatékony kezelésének. A 30-40 Hgmm alatti szöveti oxigénnyomás intő jel, miszerint a keringési állapot, a perfúzió javítása nélkül a sebgyógyulás nem valószínú. A $\mathrm{TcPO}_{2}$-eljárás korlátját jelentheti az egyidejü neuropathia, fekély, infekció jelenléte, ami az ischaemia kimutatásának érzékenységét csökkentheti [27]. A Doppler- és szöveti oxigénmérésen alapuló eljárások határértékeit az 1 . táblázatban tüntettük fel.

A magasabb szintű képalkotó eljárások (digitális szubsztrakciós angiográfia, CT/MR angiográfia) nem elsősorban az érszúkület tényének kimutatására szolgálnak, hanem sokkal inkább a felismert érszúkület esetén szükségesnek ítélt revascularisatio (érsebészeti vagy endovascularis) tervezésében segítenek [13].

\section{Alsó végtagi verőérszülkület és diabetes együttesének kezelési szempontjai. Prevenció és revascularisatio}

\section{A prevenció lehetóségei}

Az epidemiológiai adatok arra utalnak, hogy a cukorbeteg populációban a szív- és keringési megbetegedés és halálozás kockázatának egyik fó meghatározója a perifériás verőérbetegség. Ennek megfelelően a prevenció első lépése az érszúküulet felismerése [28]. A továbbiakban a megelőzés célja a szisztémás atherosclerosis szövődményeinek (myocardialis infarctus, stroke, cardiovascularis halálozás) elkerülése, valamint az alsó végtagi tünetek enyhítése, illetve az amputáció kockázatának csökkentése. Alsó végtagi keringészavar és cukorbetegség együttese esetén az irányelvek komplex életmódbeli és gyógyszeres kezelést javasolnak. 
1. táblázat |A Doppler- és szövetioxigén-mérések határértékei

\begin{tabular}{|c|c|c|c|}
\hline Doppler-vizsgálat & $\begin{array}{l}\text { Nyomásindex } \\
\text { Boka/kar index } \\
>1,4-\text { nem komprimálható } \\
0,91-1,3 \text { - normális } \\
0,9-0,7-\text { enyhe érszúkület } \\
0,7-0,4-\text { közepes fokú érszúkület } \\
<0,4 \text { súlyos érszúkület } \\
\text { Öregujj/kar index } \\
<0,7 \text { érszúkület } \\
<0,25 \text { kritikus keringészavar }\end{array}$ & $\begin{array}{l}\text { Bokanyomás }<50 \text { Hgmm - } \\
\text { kritikus keringészavar } \\
\text { Ujjnyomás <30 Hgmm - kritikus } \\
\text { keringészavar }\end{array}$ & $\begin{array}{l}\text { Hullámgörbe } \\
\text { Érszúkület: } \\
\text { Trifázisos jelleg megszúnése } \\
\text { vagy } \\
\text { ellenoldalhoz képest } \\
\text { a hullámamplitúdó 50\%-ot } \\
\text { meghaladó csökkenése } \\
\text { vagy } \\
\text { reverz áramlás megszúnése }\end{array}$ \\
\hline $\begin{array}{l}\text { Szöpeti oxigén parciális nyomás } \\
\left(\mathrm{TcPO}_{2}\right)\end{array}$ & $\begin{array}{l}>50 \text { Hgmm - jó esély } \\
\text { a fekélygyógyulásra } \\
<30 \text { Hgmm csekély esély } \\
\text { a fekélygyógyulásra }\end{array}$ & & \\
\hline
\end{tabular}

Előbbi része az elhízás elleni összetett életmódváltás, a dohányzás felfüggesztése, valamint a rendszeres, lehetőleg kontrollált fizikai tréning. A gyógyszeres megelőzés magában foglalja a lipidanyagcsere hatékony kezelését (statinterápia) a célértékek figyelembevételével, a szénhidrát-anyagcsere kontrollját, valamint a vérnyomásértékek normális szinten tartását. Elengedhetetlen a thrombocytaaggregáció gátlása, amely a hazai körülmények között elsősorban aszpirin- vagy clopidogrelkészítmény adását jelenti. Amennyiben alsó végtagi claudicatiós panaszok jelentkeznek, javasolható különböző vazoaktív szerek (cilosztazol, naftidrofuryl, pentoxyphyllin, sulodexid) alkalmazása $[29,30]$. A komplex prevenció csak beteggondozás formájában képzelhető el, amelyben a családorvosok, a diabetológiai és angiológiai szakambulanciák hathatós együttmúködése elengedhetetlen. Amennyiben a végtag keringésének romlása indokolja, alsó végtagi revascularisatio válhat szükségessé, aminek eredményességét a hatékony gyógyszeres kezelés is megalapozza.

\section{Az alsó végtagi revascularisatio lehetôségei cukorbetegségben}

\section{A revascularisatio indikációjának felállitása}

A diabeteses láb jelenségkörén belül a szöveti oxigenizáció, szöveti hipoperfúzió tartós és progresszív romlása az egyik kulcsmozzanat, amely a végtagvesztés vagy infek- ció/szepszis veszélyét is magában hordozó kritikus végtagi ischaemia állapotához vezethet. A keringési zavar késői felismerésének a kockázatát is figyelembe véve, a diabetesgondozásban a perfúzióorientált ellátási szemléletnek mind nagyobb jelentőséget tulajdonítunk.

A revascularisatiós aktivitás szempontjából fontos a diabeteses angiopathia anatómiai megoszlása az alsó végtagon belül. Míg az aorta distalis harmadától a medencei artériákon át a femoralis ütőerekig az atherosclerosis előfordulása dominál és mutat életkori összefüggést, addig a diabeteses angiopathia elsősorban a térd szintjétől lefelé érinti az artériákat. Az alsó végtagi érszúkület többszörös kockázata (növekvő élettartam, dohányzás, cukorbetegség) miatt az alsó végtagi revascularisatio során leggyakrabban többszintü, többszörös atheroscleroticus és diabeteses, flow-limitáló elváltozásokat együtt találunk.

Az alsó végtagi keringés helyreállítása, a revascularisatio indokolt, amennyiben a végtagi keringészavar a beteg életminőségét markánsan rontja (claudicatio), valamint a végtag életképessége kérdésessé válik (kritikus végtagi ischaemia).

A beavatkozás indikációjának felállítása rendkívül öszszetett szempontrendszer átgondolását igényli. A cukorbetegekben a klinikai tünetek (claudicatio) sokkal nehezebben értelmezhetők, így a perfúzióromlás objektív igazolása elsődleges. A cukorbetegek végtagvesztésének kockázatát döntően három tényező határozza meg: 1. a szöveti károsodás (fekély, gangraena) jelenléte, 2 . az infekció és 3. az alsó végtagi keringés károsodása. Ha a 
három tényező mértékét is figyelembe vesszük, úgy a végtagvesztés kockázatát jelző klinikai kockázatbecslő rendszer fogalmazható meg, ami segíthet az érbeavatkozás mérlegelésekor. A rendszert finomíthatja, ha a sebkezelésre, infekciókontrollra adott választ is figyelembe vesszük [31]. Amennyiben az utóbbi eltérések a standard kezelés mellett nem kielégítóen gyógyulnak, úgy az ischaemia megszüntetése különösen fontossá válik. Az ischaemia mértékének értékelése különbözik nem cukorbetegben és cukorbetegekben. Utóbbiak esetén a nem komprimálható artériák okozta boka/kar index értékelési nehézség, valamint a nehezen gyógyuló, gyakran infekciót mutató fekélyek jelenléte miatt az alsó végtagi keringészavar enyhébb foka esetén is célszerünek mutatkozik a revascularisatio [32].

$\mathrm{Az}$ alsó végtagi keringés helyreállításának alapfeltétele az érpálya minél részletgazdagabb ábrázolása. A megfelelő képfelbontás biztosítása cukorbetegek esetén kiemelten fontos, hiszen gyakori a lábszár vagy lábfeji artériák érintettsége. A rendelkezésre álló képalkotó eljárások közül ebből a szempontból a digitális szubsztrakciós angiográfiának (DSA) kiemelt jelentősége van. Az alternatívaként rendelkezésre álló, nem cukorbetegekben egyre elterjedtebben használt $\mathrm{CT} / \mathrm{MR}$ angiográfia alkalmazhatóságát cukorbetegekben több tényező is csökkenti. A CT-angiográfia esetén az érfali kalcifikáció okozta mütermékek különösen a térd alatti régióban megnehezítik az értékelhetôséget. Mind a két modalitás esetén a kontrasztanyag alkalmazhatóságának korlátot szab a gyakori együttesen fennálló vesefunkció-romlás. Különösen igaz ez akkor, ha a képalkotást endovascularis beavatkozás követné ismételt kontrasztanyag-expozícióval. A DSAvizsgálat primer alkalmazása pedig természetesen magában rejti az invazivitással járó kockázatot [33].

A pontos anatómiai szituáció ismeretében, a végtagvesztés kockázatának mérlegelését követően, a keringés javítását nyitott érsebészeti mütét vagy endovascularis beavatkozás biztosíthatja. A kéttípusú beavatkozás bizonyos esetekben akár egy ülésben is végezhető (hibrid beavatkozások). Az érsebészeti vagy katéteres beavatkozás közötti döntést több szempontrendszer egyidejű mérlegelése határozza meg. A két beavatkozástípus egyformán alkalmas az érátjárhatóság biztosítására, azonban általános trend az endovascularis módszer előtérbe kerülése. Ennek magyarázata a minimális invazivitás igénye, ami különösen fontos lehet a számos társbetegségtől szenvedő cukorbetegekben. Emellett az aktuálisan fennálló fekélyek is inkább az endovascularis beavatkozás melletti döntést támogatják [34].

A két módszer közötti döntésben a keringészavart okozó érelzáródás anatómiai mintázatán túl a beteg kísérő betegségei, életkora, az ellátóhely eszközös és humán erőforrás-ellátottsága mind olyan tényezők, amelyek együttes figyelembevétele elengedhetetlen. Mindez az adott egészségügyi szolgáltató intézetben múködő vas- cularis team jelenlétét igényli, amelyben angiológusok, érsebészek és intervenciós radiológusok egyenrangú félként segítik az ellátás optimális tervezését [32].

\section{Alsó végtagi érsebészeti beavatkozások szempontjai cukorbetegeken}

Diabeteses betegen a térd feletti szakaszon kialakult elzáródás esetén érsebészeti megoldásként bypassmütét alkalmazása jön szóba $[35,36]$, a desobliteratiós módszer a falálló, érfalmerevítő mész, úgynevezett Mönckenberg-féle mediasclerosis miatt nem kivitelezhető. A betegek lábán már meglévő - gyakran infekt - seb miatt a saját véna alkalmazása javasolt $[35,36]$. Nem megfelelő vagy hiányzó véna esetén alternatív megoldás a homológ graft alkalmazása, vagy gyógyult infekció esetén - térd felett - múér is alkalmazható. A mútét eredményességét a kiáramlási pálya megléte határozza meg. Diabeteses betegeknél viszont gyakrabban a térd alatti érpálya érintett. Ha az adott ér kiáramlási pályája megtartott [36], hosszú, ízületet is áthidaló, akár bokáig tartó bypassmütét is végezhető [31]. Nyitott talpi ív esetén pedalis szintű áthidalás is lehetséges [37]. Térd alatti rekonstrukcióhoz kizárólag csak saját véna, illetve homológ graft alkalmazható. Ilyen hosszú áthidalás nyitva maradási ideje korlátozott, de arra elegendő, hogy a seb meggyógyuljon, és újabb kollaterális rendszer alakuljon ki [38]. Tapasztalat szerint a bypass [36] minél rövidebb, annál jobb a nyitva maradási arány. Tartós eredmény csak meglévő, elegendő kiáramlási pálya esetén várható (legalább az adott sugárban). Több szintet érintő - azaz femoralis, poplitealis és/vagy cruralis - érterületek elzáródásakor hibrid megoldások alkalmazhatók [36], vagyis a centrális érszakaszon vénás bypass és egy ülésben intraoperatív PTA a kiáramlási pálya megnyitására, javítására vagy femoralis superficialis PTA és popliteocruralis vénás bypass. A megfelelő módszer kiválasztását a vascularis státuszon túl a beteg teherbírása, a sebészi team gyakorlata, a felhasználandó véna minősége, a sebész radiológiai gyakorlata vagy a társszakmák segítsége is döntően befolyásolja [37].

Sebésztechnikai szempontból gyakran nehézséget jelent, hogy a mediasclerosis miatt az erek nem lefoghatók, kirekesztésük csak például ballonos eszközökkel lehetséges, és az érfal varrása is gyakran rendkívül nehéz [39].

Megfelelő kiáramlási pálya hiánya esetén vagy ha a beteg rehabilitációra nem alkalmas és a várható életkilátása egyéb betegségei miatt kevesebb mint egy év, multidiszciplináris konzílium szükséges annak mérlegelésére, hogy szabad-e a beteget egy többórás helyreállító érmútétnek kitenni [40]. Phlegmone, humid gangraena, pus esetén eldöntendő kérdés, hogy az érsebészeti beavatkozás előtt vagy alatt kerüljön sor a gangraenás régió feltárására [40]. Rekonstrukciós beavatkozás során végzett necrectomia esetén a seb nyitva kezelése javasolt. 


\section{Alsó végtagi endovascularis érbeavatkozások sajátosságai cukorbetegségben}

Az endovascularis beavatkozások sikerének feltételei: a behatolás helyének helyes kiválasztása, a rekanalizáció helyének, módjának és mértékének gondos mérlegelése [41].

$\mathrm{Az}$ access megfelelő pontja az, ahol a behatolási kapu biztonságos uralása mellett, a legrövidebb úton, a legkevesebb eszközös lépéssel a legtöbb ellátandó laesio érhetó el. Terápiás beavatkozást jelenleg a radialis, a brachialis, a femoralis (mindkét irányba), a poplitea (retrográd) és a pedalis (arteria tibialis anterior, arteria dorsalis pedis, arteria tibialis posterior retrográd) artériák szúrásából végzik.

Tekintettel arra, hogy a diabetes okozta érelváltozások a térd alatti területeken dominálnak, és jellemzően több kiáramlási artériát és azokat hosszú szakaszon érintik, az endovascularis ellátást lehetőleg femoralis anterográd behatolásból javasolt végezni.

Azokban az esetekben, amikor az atheroscleroticus, magasabb lokalizációjú szúkületekkel együtt jelentkező (úgynevezett emeletes, kevert) diabeteses érelváltozások a jellemzőek, az optimális femoralis anterográd behatolás helyett az ellenoldali, úgynevezett cross-over megkö-
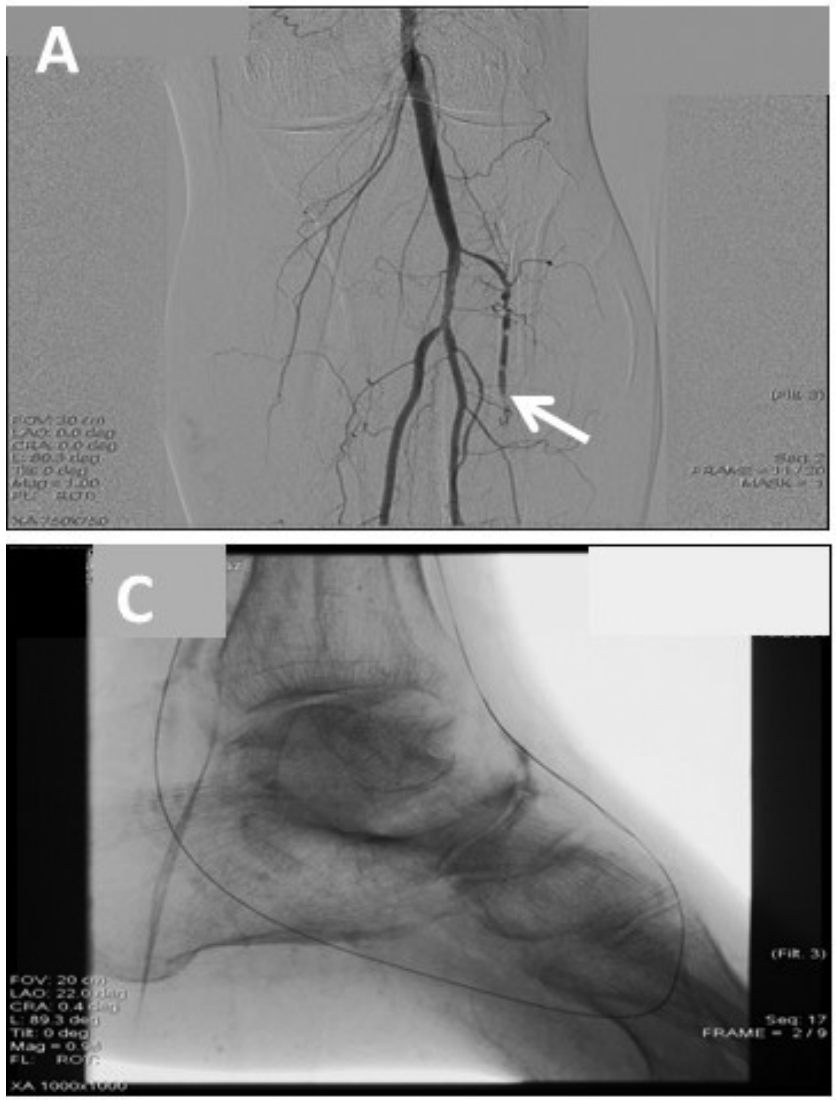

zelítés javasolható az adott végtag artériás rendszerének az iliacalis szinttől a lábig terjedő terápiás elérésére.

A hosszú szakaszú, részben meszes, régi és szervülő thrombussal kombinált elzáródások egy részénél a vezetődróttal megkezdett anterográd átjutás elakad, sikertelen. Ekkor a pedalis szinten ábrázolható, nyitva levő, az úgynevezett „landolási zónát” jelentő artériák (arteria dorsalis pedis, arteria tibialis posterior) direkt és retrográd punkciója felól vezetett dróttal sikerülhet átjutni a „fentről” nem rekanalizálható elzáródáson. Egy adott elzáródás ilyen módon lehetséges kétirányú rekanalizációs megközelítése egy időben és egy ülésben kombinálható is az úgynevezett rendezvous módszer során (4. ábra).

$\mathrm{Az}$ endovascularis beavatkozás alapelve lehet az érlumen beszúkuülését vagy teljes átjárhatatlanságát okozó elváltozás „oldalra nyomása” (ballonos tágítás, stentelés). Emellett lehetőség van a lumen szúkuület/elzáródás okának mechanikus megszüntetésére (mechanikus thrombectomiás eszközök és technikák), valamint az elfolyási akadály lumenből/szervezetből történő eltávolítására (aspirációs módszerek). Az intraluminalis rekanalizáció mellett a keringés biztosításának speciális módja, ha nem a lumen rekonstrukcióját, hanem az elzáródott lumenszakasz megkerülését célozzuk meg, és az érfal
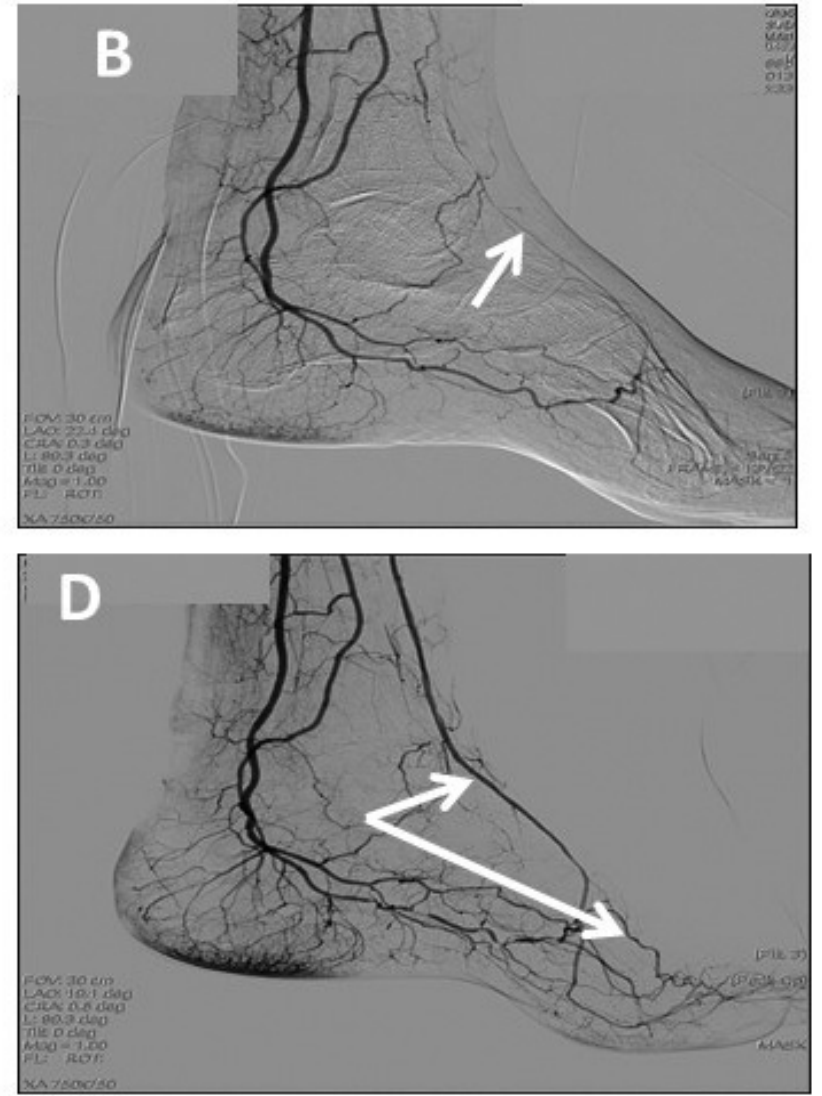

\footnotetext{
4. ábra

Perifériás, térd alatti intervenció (Dr. Bánsághi Zoltán anyagából)

A) Arteria tibialis anterior elzáródása (nyíl)

B) Következményes lábháti értelődés hiánya (nyíl)

C) Bidirekcionális revascularisatio két irányból vezetett dróttal a talpi arcuson át

D) A megnyitott arteria tibialis anterior, arteria dorsalis pedis (nyíl) és a jól telődő talpi ív kielégítő értelődést ad a lábelőn (nyílak)
} 
subintimalis rétegének szabályozott dissectióját előidézve, egy új lumen kialakításával „megkerüljük” az intraluminalis stenoocclusiót. Ezt subintimalis rekanalizációnak nevezzük. Ezt a lehetőséget döntően a comb területén használják.

$\mathrm{Az}$ endovascularis rekanalizáció eszköztára többféle beavatkozást tesz lehetővé. Alapeszköz a kezelendő elváltozáson átjuttatott vezetődróton keresztül felvezetett értágító ballon. A tágítási eredmény javítására és a hoszszú távú nyitva maradás segítésére használhatják a pengékkel ellátott vágóballont (cutting ballon), citosztatikus anyaggal fedett gyógyszerkibocsátó ballont (DEB) vagy fagyasztó ballont (cryoballon). Amennyiben a dilatatív lépés nem eredményezi az érpálya jó lumenű stabil remodellálását, úgy a ballonos tágítási eredmény stabilizálására fém cső-hálók, stentek beültetése szükséges.

Itt öntáguló és ballontágításos stentek ismertek. A stentek mint implantátumok beültetésének szövődményeként jelentkező intimaburjánzás „kezelésére” a citosztatikus drogokkal bevont, úgynevezett gyógyszerkibocsátó stentek (DES) vagy jelenleg már az intimatúlprodukciót nem okozó, 5-12 hét alatt „felszívódó”, úgynevezett biodegradábilis stenteket használjuk. Anyaguk szerint szén, tejsav, magnézium a leggyakoribb. A stentek fedett változata a stentgraft, amit érsérülések esetén a lumen folytonosságának újraalkotására, de az erős intimatúlprodukció elkerülésére is használhatunk. Diabetesben a megváltozott thromboticus aktivitás miatt nem ritka emboliák kezelésénél a thrombustömeg eltávolítása (lysis, aspiráció) az elsődleges, amihez aspirációs és lysiskatétereket használnak. Itt a lokális, intraarterialis thrombusoldás gyógyszeresen is elősegíthető, legtöbbször rTPA, ritkábban sztreptokináz adásával. A hosszú, nem dilatálható, erősen meszes elzáródásokban vagy szervülő thromboembolusokban forgó mozgást végző thrombectomiás eszközök is alkalmazhatóak.

A rekanalizáció mértékére vonatkozólag fontos szempont, hogy a revascularisatiós múvelet időbeli nyúlásával a beavatkozási embologén szövődmények valószínüsége nő, ezért az „elégséges rekanalizáció” empirikus és teljesen individuális mértékének megtalálására kell törekedni $[42,43]$.

\section{Következtetés}

A diabeteses láb problematikája jósolhatóan az egészségügyi ellátás egyik központi témája lesz az elkövetkező évtizedekben. Ez részben köszönhető a perifériás érbetegség [44], a cukorbetegség globális mértékű gyakoribbá válásának [45], valamint a nyugati típusú társadalmakban tapasztalható öregedésnek [46]. Az 1990-es években közölt adatokhoz képest megduplázódott azok aránya, akik esetén a diabeteses láb szindróma etiológiájában a keringési zavar jelentős szerepet játszik [32]. Az ischaemiás komponens magas aránya, valamint a fekélyképződésben és amputációs kockázatban betöltött kiemelt szerepe alapján úgy fogalmazhatunk, hogy minden diabeteses lábfekély ischaemiás eredetünek tekintendő, amíg ennek ellenkezője be nem bizonyosodik [40]. Cukorbetegekben a keringési zavar kimutatása a nem cukorbetegekkel összevetve problematikus. A vascularis kivizsgálás az alapvizsgálatokon túl sokszor arra hivatott érspecialista bevonását igényli. A megfelelő életmód-változtatás mellett a gyógyszeres kezelés elengedhetetlen. Mindezen túl a perfúzióorientált megközelítésnek kiemelt szerepe van. A revascularisatio optimális kivitelezésének alapfeltétele a megfelelő időzítés, a beavatkozás módjának gondos mérlegelése és a későbbi beteggondozás. Mindez feltételezi a területi elven létrehozandó vascularis centrumok optimális múködését, amelyekben angiológusok, érsebészek és intervenciós radiológusok (vascularis team) a társszakmák (diabetológia, ortopédia, plasztikai sebészet, neurológia, bőrgyógyászat) bevonásával hozhatják meg a szükséges döntéseket. Utóbbi jelentősége abban van, hogy csak így, a multidiszciplinaritás érvényesítésével lehetséges a diabeteses láb komplex kórképének minden elemét (ischaemia, neuropathia, csont- és ízületi deformitás, infekció) egységben tekinteni, ami a hatékony kezelés előfeltétele.

Anyagi támogatás: A közlemény megírása anyagi támogatásban nem részesült.

Szerzői munkamegosztás: K. E., B. Z., SZ. G. V.: Az irodalmi háttér elemzése, a közlemény szövegének megfogalmazása. J. Z., F. K.: Az összefoglaló közlemény kritikai olvasata, annak tartalmi és stilisztikai javítása. A cikk végleges változatát valamennyi szerző elolvasta és jóváhagyta.

Érdekeltségek: A szerzőknek nincsenek érdekeltségeik.

\section{Irodalom}

[1] Boulton, A. J.: The diabetic foot: grand overview, epidemiology and pathogenesis. Diabetes Metab. Res. Rev., 2008, 24(Suppl. 1), S3-S6.

[2] Jermendy, Gy.: The diabetic foot syndrome: pathomechanism, clinical picture, current treatment and prevention. [Diabeteses láb szindróma: patomechanizmus, klinikai kép, korszerű terápia, megelőzés.] LAM, 2012, 22(4), 249-256. [Hungarian]

[3] Kolosswáry, E., Járai, Z., Farkas, K.: Peripheral arterial disease and diabetes related lower limb amputations. Presentation of the epidemiological data and the analysis of potentialities in preventive strategy. [A perifériás verőérbetegséggel és a cukorbetegséggel összefüggó alsó végtagi amputációk. Epidemiológiai adatok bemutatása és a megelőző stratégia lehetőségeinek elemzése.] Orv. Hetil., 2016, 157(32), 1266-1274. [Hungarian]

[4] Jude, E. B., Eleftheriadou, I., Tentolouris, N.: Peripheral arterial disease in diabetes: a review. Diabet. Med., 2010, 27(1), 4-14.

[5] Thiruvoipati, T., Kielhorn, C. E., Armstrong, E. J.: Peripheral artery disease in patients with diabetes: Epidemiology, mechanisms, andoutcomes. World J. Diabetes, 2015, 6(7), 961-969.

[6] Adler, A. I., Stevens, R. J., Neil, A., et al.: UKPDS 59: hyperglycemia and other potentially modifiable risk factors for peripheral vascular disease in type 2 diabetes. Diabetes Care, 2002, 25(5), 894-899. 
[7] Becker, F., Robert-Ebadi, H., Ricco, J. B., et al.: Chapter I. Definitions, epidemiology, clinical presentation and prognosis. Eur. J. Vasc. Endovasc. Surg., 2011, 42(Suppl. 2), S4-S12.

[8] Abola, M. T., Bhatt, D. L., Duval, S., et al., on behalf of the REACH Investigators: Fate of individuals with ischemic amputations in the REACH Registry: three-year cardiovascular and limb-related outcomes. Atherosclerosis, 2012, 221(2), 527-535.

[9] Apelqvist, J. A., Lepäntalo, M. J.: The ulcerated leg: when to revascularize. Diabetes Metab. Res. Rev., 2012, 28(Suppl. 1), 3035.

[10] Prompers, L., Schaper, N., Apelqvist, J., et al.: Prediction of outcome in individuals with diabetic foot ulcers: focus on the differences between individuals with and without peripheral arterial disease. The EURODIALE Study. Diabetologia, 2008, 51(5), 747-755.

[11] Akbtar, S., Schaper, N., Apelqvist, J., et al.: A review of the Eurodiale studies: what lessons for diabetic foot care? Curr. Diab. Rep., 2011, 11(4), 302-309.

[12] Kolossváry, E., Ferenci, T., Kováts, T., et al.: Trends in major lower limb amputation related to peripheral arterial disease in Hun gary: A nationwide study (2004-2012). Eur. J. Vasc. Endovasc. Surg., 2015, 50(1), 78-85.

[13] Brownrigg, J. R., Schaper, N. C., Hinchliffe, R. J.: Diagnosis and assessment of peripheral arterial disease in the diabetic foot. Diabet. Med., 2015, 32(6), 738-747.

[14] Dolan, N. C., Liu, K., Criqui, M. H., et al.: Peripheral artery disease, diabetes, and reduced lower extremity functioning. Diabetes Care, 2002, 25(1), 113-120.

[15] Boyko, E. J., Ahroni, J. H., Davignon, D., et al.: Diagnostic utility of the history and physical examination for peripheral vascular disease among patients with diabetes mellitus. J. Clin. Epidemiol., 1997, 50(6), 659-668.

[16] Aerden, D., Massaad, D., von Kemp, K., et al.: The ankle-brachial index and the diabetic foot: a troublesome marriage. Ann. Vasc. Surg., 2011, 25(6), 770-777.

[17] Nam, S. C., Han, S. H., Lim, S. H., et al.: Factors affecting the validity of ankle-brachial index in the diagnosis of peripheral arterial obstructive disease. Angiology, 2010, 61(4), 392-396.

[18] Young, M. J., Adams, J. E., Anderson, G. F., et al.: Medial arterial calcification in the feet of diabetic patients and matched non-diabetic control subjects. Diabetologia, 1993, 36(7), 615-621.

[19] Potier, L., Halbron, M., Bouilloud, F., et al.: Ankle-to-brachial ratio index underestimates the prevalence of peripheral occlusive disease in diabetic patients at high risk for arterial disease. Diabetes Care, 2009, 32(4), e44.

[20] Aboyans, V., Ho, E., Denenberg, J. O., et al.: The association between elevated ankle systolic pressures and peripheral occlusive arterial disease in diabetic and nondiabetic subjects. J. Vasc. Surg., 2008, 48(5),1197-1203

[21] Jude, E. B., Oyibo, S. O., Chalmers, N., et al.: Peripheral arterial disease in diabetic and nondiabetic patients: a comparison of severity and outcome. Diabetes Care, 2001, 24(8), 1433-1437.

[22] Ro du, H., Moon, H. J., Kim, J. H., et al.: Photoplethysmography and continuous-wave Doppler ultrasound as a complementary test to ankle-brachial index in detection of stenotic peripheral arterial disease. Angiology, 2013, 64(4), 314-320.

[23] Tehan, P. E., Bray, A., Chuter, V. H.: Non-invasive vascular assessment in the foot with diabetes: sensitivity and specificity of the ankle brachial index, toe brachial index and continuous wave Doppler for detecting peripheral arterial disease. J. Diabetes Complications, 2016, 30(1), 155-160.

[24] Brownrigg, J. R., Schaper, N. C., Hinchliffe, R. J.: Diagnosis and assessment of peripheral arterial disease in the diabetic foot. Diabet. Med., 2015, 32(6), 738-747.

[25] Young, M. J., Adams, J. E., Anderson, G. F., et al.: Medial arterial calcification in the feet of diabetic patients and matched non-diabetic control subjects. Diabetologia, 1993, 36(7), 615-621.

[26] Williams, D. T., Harding, K. G., Price, P.: An evaluation of the efficacy of methods used in screening for lower-limb arterial disease in diabetes. Diabetes Care, 2005, 28(9), 2206-2210.
[27] Kalani, M., Brismar, K., Fagrell, B., et al.: Transcutaneous oxygen tension and toe blood pressure as predictors for outcome of diabetic foot ulcers. Diabetes Care, 1999, 22(1), 147-151.

[28] Mohammedi, K., Woodward, M., Hirakawa, Y., et al.: Presentations of major peripheral arterial disease and risk of major outcomes in patients with type 2 diabetes: results from the ADVANCE-ON study. Cardiovasc. Diabetol., 2016, 15, 129.

[29] Rydén, L., Grant, P. J., Anker, S. D., et al.: ESC Guidelines on diabetes, pre-diabetes, and cardiovascular diseases developed in collaboration with the EASD: the Task Force on diabetes, prediabetes, and cardiovascular diseases of the European Society of Cardiology (ESC) and developed in collaboration with the European Association for the Study of Diabetes (EASD). Eur. Heart J., 2013, 34(39), 3035-3087.

[30] Keresztes, K.: Characteristics and treatment of peripheral arterial disease in diabetes. [A perifériás verőérbetegség jellemzőo és kezelése diabéteszben.] Metabolizmus, 2016, 14(4), 274-281. [Hungarian]

[31] Mills, J. L. Sr., Conte, M. S., Armstrong, D. G., et al.: The Society for Vascular Surgery Lower Extremity Threatened Limb Classification System: risk stratification based on wound, ischemia, and foot infection (WIfI). J. Vasc. Surg., 2014, 59(1), 220-234.el-2.

[32] Hingorani, A., LaMuraglia, G. M., Henke, P., et al.: The management of diabetic foot: A clinical practice guideline by the Society for Vascular Surgery in collaboration with the American Podiatric Medical Association and the Society for Vascular Medicine. J. Vasc. Surg., 2016, 63(2), Suppl., 3S-21S.

[33] Pomposelli, F.: Arterial imaging in patients with lower extremity ischemia and diabetes mellitus. J. Vasc. Surg., 2010, 52 (3 Suppl.), 81S-91S.

[34] Peter-Riesch, B.: The diabetic foot: The never-ending challenge. Endocr. Dev., 2016, 31, 108-134.

[35] Acsády, Gy., Nemes, A.: Textbook of chirurgia vascolare. Chapter 11, Diabetic foot. [Az érsebészet tankönyve. 11. fejezet, Diabeteses láb.] Medicina Könyvkiadó, Budapest, 2001, 163-167. [Hungarian]

[36] Apelqvist, J. A., Lepäntalo, M. J.: The ulcerated leg: when to revascularize. Diabetes Metab. Res. Rev., 2012, 28(Suppl. 1), 3035 .

[37] Kota, S. K., Kota, S. K., Meher, L. K., et al.: Surgical revascularization techniques for diabetic foot. J. Cardiovasc. Dis. Res., 2013, $4(2), 79-83$.

[38] Gibbons, G. W.: Lower extremity bypass in patients with diabetic foot ulcers. Surg. Clin. North Am., 2003, 83(3) 659-669.

[39] Lepäntalo, M., Biancari, F., Tukiainen, E.: Never amputate without consultation of a vascular surgeon. Diabetes Metab. Res. Rev., 2000, 16(Suppl. 1), S27-S32.

[40] Lepäntalo, M., Apelqvist, J., Setacci, C., et al.: Chapter V: Diabetic foot. Eur. J. Vasc. Endovasc. Surg., 2011, 42(Suppl. 2), S60-S74.

[41] Apelqvist, J.: Diagnostics and treatment of the diabetic foot. Endocrine, 2012, 41(3), 384-397.

[42] Reekers, J. A.: Interventional radiology in the diabetic lower extremity. Med. Clin. North Am., 2013, 97(5), 835-845.

[43] Georgakarakos, E., Papanas, N., Papadaki, E., et al.: Endovascular treatment of critical ischemia in the diabetic foot: new thresholds, new anatomies. Angiology, 2013, 64(8), 583-591.

[44] Lam, D. W., LeRoith, D.: The worldwide diabetes epidemic. Curr. Opin. Endocrinol. Diabetes Obes., 2012, 19(2), 93-96.

[45] Fowkes, F. G., Rudan, D., Rudan, I., et al.: Comparison of global estimates of prevalence and risk factors for peripheral artery disease in 2000 and 2010: a systematic review and analysis. Lancet, 2013, 382(9901), 1329-1340.

[46] Pew Research Center, January 30, 2014. Attitudes about Aging: a global perspective. http://www.pewglobal.org/2014/01/30/ attitudes-about-aging-a-global-perspective/ (accessed 18.10.2016)

(Kolossváry Endre dr., Budapest, Tétényi út 12-16., 1115 e-mail: kolossendre@gmail.com) 